\title{
miR-497 and miR-34a retard lung cancer growth by co-inhibiting cyclin E1 (CCNE1)
}

\author{
Zhiyuan Han ${ }^{1}$, Yanbin Zhang², Qiaoyuan Yang ${ }^{1}$, Binbin Liu ${ }^{1}$, Jianjun Wu ${ }^{1}$, Yajie \\ Zhang ${ }^{3}$, Chengfeng Yang ${ }^{4}$ and Yiguo Jiang ${ }^{1}$ \\ 1 State Key Laboratory of Respiratory Disease, Institute for Chemical Carcinogenesis, Guangzhou Medical University, \\ Guangzhou, PR China \\ 2 Department of Pulmonary Tuberculosis, Guangzhou Chest Hospital, Guangzhou, PR China \\ ${ }^{3}$ Department of Pathology, Guangzhou Medical University, Guangzhou, PR China \\ ${ }^{4}$ Department of Physiology and Center for Integrative Toxicology, Michigan State University, East Lansing, MI, USA \\ Correspondence to: Yiguo Jiang, email: jiangyiguo@vip.163.com
}

Keywords: CCNEl, lung cancer, miR-34a, miR-497

Received: January 05, $2015 \quad$ Accepted: March 02, 2015

Published: March 29, 2015

This is an open-access article distributed under the terms of the Creative Commons Attribution License, which permits unrestricted use, distribution, and reproduction in any medium, provided the original author and source are credited.

\section{ABSTRACT}

Cyclin E1, encoded by the CCNE1 gene, promotes G1/S transition, chromosome instability, and oncogenesis. Here, we show that miR-497 and miR-34a target the 3'-UTR of CCNE1. miR-497 and miR-34a are downregulated in cancer cells and their ectopic expression inhibited cell proliferation and colony formation in vitro, and inhibited tumor growth in a xenograft model. The effect of simultaneous overexpression of $\mathrm{miR}-\mathbf{4 9 7}$ and $\mathrm{miR}-34 \mathrm{a}$ on the inhibition of cell proliferation, colony formation, and tumor growth, and the downregulation of cyclin E1 was stronger than the effect of each miRNA alone. The synergistic actions of miR-497 and miR34a partly correlated with cyclin E1 levels. When cells stably expressing CCNE1 were transfected with the Hi-miR-497/34a plasmid, there was no effect on colony formation, compared with that of cells transfected with either Hi-miR497 or HimiR34a. These results indicate cyclin E1 is downregulated by both miR-497 and miR$34 a$, which synergistically retard the growth of human lung cancer cells.

\section{INTRODUCTION}

Cancer is a complex disease caused by the progressive accumulation of genetic and epigenetic alterations in cells, which allow the cells to evade normal and environmental controls. Much progress has been made in the treatment of lung cancer in the last 10 years. Nonetheless, lung cancer is currently the most common cause of cancer-related death throughout the world, and therefore remains an unresolved medical issue. An understanding of the processes and pathogenesis of cancer at the systemic, cellular, and molecular levels is one of the most ambitious goals of cancer research. MicroRNAs (miRNAs) are epigenetic regulators that play a pivotal role in the acquisition of tumorigenic properties by cells.

miRNAs are a class of endogenous noncoding RNAs of approximately 22 nucleotides (nt) that regulate mRNA stability and translation [1-3]. A wide range of biological functions are controlled by miRNAs, including cell proliferation, differentiation, and apoptosis [4-6]. There is strong evidence that miRNAs can act as oncogenes or tumor suppressors, with key roles in cancer initiation, progression, and therapy. In an attempt to understand the mechanisms underlying cancer, an increasing number of studies have reported that individual miRNAs exert their functions in specific cancers. Many recent studies reported that some miRNAs cooperatively control a variety of biological processes, including cell development and differentiation, apoptosis, and the cell cycle [7-10]. When an mRNA or several different mRNAs involved in a specific biological process are targeted by several miRNAs, the miRNAs act cooperatively. Recent studies have demonstrated that miRNAs encoded in miRNA clusters function synergistically in cancer, e.g., the miR-17-92 cluster [11-13] and the miR-15a-16-1 cluster $[14,15]$. Ventura et al. reported that miR-17-92 and miR-106b-25 double-knockout mice have a more severe phenotype than miR-17-92 single-knockout mice [16]. 
In our previous study [17], we profiled miRNA expression in lung cancer cells treated with resveratrol, a potential cancer chemopreventive agent. We found nine miRNAs (miR-622, -512-5p, -504, -497, -34a, -302d, $\left.-302 b^{*},-29 c,-20 b\right)$ upregulated in the cells. Only miR$622,-497$, and $-34 \mathrm{a}$ inhibited the proliferation of lung cancer cells, whereas the remaining six miRNAs had no effect on cell proliferation in our preliminary experiments. miR-497 and -34a have a similar seed sequence, indicating that they might share similar functions; therefore, in the present study, these miRNAs were selected for the identification of potential targets and to explore their roles in lung cancer. Bioinformatics analysis suggested that both miRNAs target the CCNE1 gene, which encodes Cyclin E1. Cyclin E1, a member of the conserved cyclin E family, activates CDK2 [18] and regulates the transition of mammalian cells from quiescence to $\mathrm{S}$ phase. Transgenic cyclin E1 triggers dysplasia and multiple pulmonary adenocarcinomas $[19,20]$, and the overexpression of cyclin E1 was suggested to contribute to cancer development or tumorigenesis in various types of cancer, including breast, colon, and lung cancers [21]. Increased expression of cyclin E1 is a useful marker of poor prognosis in lung cancer [22]. These data suggest that cyclin E1 is a potential target for the treatment of lung cancer. Based on previous data, we designed a study to test the hypothesis that cyclin E1 expression is coregulated by miR-497 and miR-34a in lung cancer.

\section{RESULTS}

\section{miR-497 and miR-34a inhibit the proliferation of human lung cancer cells}

miR-34a is downregulated in lung cancer tissues and cells [23, 24]; however, few reports have examined the expression of miR-497 in lung cancer. Although miR-497 is downregulated in lung cancer $[25,26]$, its specific role remains to be determined. Analysis of the expression of miR-497 and miR-34a in lung cancer cells showed that the levels of miR-497 and miR-34a (Figure 1a) were reduced by $24.29 \pm 2.50 \%$ and $9.43 \pm 2.96 \%$ in A549, $16.11 \pm$ $5.20 \%$ and $4.51 \pm 0.34 \%$ in $\mathrm{H} 460,53.55 \pm 9.28 \%$ and $18.25 \pm 2.14 \%$ in $\mathrm{H} 1299,43.00 \pm 15.46 \%$ and $87.01 \pm$ $27.73 \%$ in $\mathrm{H} 446$, and $42.17 \pm 4.26 \%$ and $32.04 \pm 4.58 \%$ in QG56 lung cancer cells, respectively, compared to those in normal bronchial epithelial 16HBE cells.

The cell viability of A549, H460, and H1299 lung cancer cells was decreased by $66.71 \pm 1.65 \%, 46.36 \pm$ $1.96 \%$ and $72.10 \pm 4.02 \%$, respectively, in response to miR-34a overexpression, and by $60.71 \pm 4.63 \%, 74.94$ $\pm 3.58 \%$, and $73.71 \pm 6.50 \%$, respectively, in response to miR-497 overexpression (Figure 1b). Downregulation of the expression of miR-34a (Figure S1a) or miR-497
(Figure S1b) with inhibitors had no effect on the growth of A549, H460, and H1299 cells (Figure S1c) because the endogenous levels of these miRNAs in these cells are low. To identify the phase of the cell cycle at which the miRNAs exert their proliferation-inhibitory effect, cell-cycle distribution was analyzed by flow cytometry. Transfection with miR-497 or miR-34a mimics caused cell-cycle arrest at $\mathrm{G}_{0} / \mathrm{G}_{1}$ phase in A549, H1299, and H460 lung cancer cells (Figure 1c). Typical histograms of the cell-cycle arrest induced by miR-497 or miR-34a in A549 cells are shown in Figure 1d.

\section{miR-497 and miR-34a suppress colony formation and tumorigenesis}

The effect of miR-497 and miR-34a on the colony forming ability of A549 cells was assessed. Cells transfected with miR-497 or miR-34a mimics showed fewer $(31.33 \pm 2.44$ and $21.00 \pm 4.00$ colonies per well, respectively) and smaller colonies than those observed in the control groups $(71.00 \pm 9.33$ colonies per well) (Figure 2a).

The effect of miR-497 or miR-34a on tumorigenicity was examined in vivo. The bilateral inguino-abdominal flanks of nude mice were inoculated subcutaneously (s.c.) with A549 cells transfected with normal control (NC) (left flank) or miR-497 (right flank) mimics or with NC (left flank) or miR-34a (right flank) mimics. At 5 weeks, the average volumes $\left(588.39 \pm 117.34 \mathrm{~mm}^{3}\right)$ and weights $(308.57 \pm 26.53 \mathrm{mg})$ of tumors in groups of seven mice injected with cells transfected with miR-497 mimics were lower than those $\left(1293.16 \pm 198.57 \mathrm{~mm}^{3}\right.$ and $427.14 \pm$ $365.31 \mathrm{mg}$ ) in the control group injected with the $\mathrm{NC}$ mimic (Figure 2b), while the average volumes (190.25 \pm $\left.67.79 \mathrm{~mm}^{3}\right)$ and weights $(72.86 \pm 31.84 \mathrm{mg})$ of tumors in mice injected with cells transfected with miR-34a mimics were lower than those $\left(913.14 \pm 455.23 \mathrm{~mm}^{3}\right.$ and 287.20 $\pm 131.09 \mathrm{mg}$ ) in the control group injected with the $\mathrm{NC}$ mimic (Figure 2c). This evidence collectively suggests that miR-497 and miR-34a inhibit cell growth and might function as tumor suppressors.

\section{CCNE1 is a putative target of miR-497 and miR-} $34 a$

Three bioinformatics algorithms (Targetscan 5.0, RNAhybrid 2.1, and RNA22) predicted that miR-497 and miR-34a target CCNE1, which encodes the cyclin E1 protein. The 535-nt 3' untranslated region (UTR) of CCNE1 was screened for complementarity to the seed sequences of miR-497 and miR-34a. Two predicted target sequences for miR-497 were identified at nt 223-254 and nt 467-492 (Figure S2a). The putative secondary RNA hybrids, with minimum free energy $(\Delta G)$, are shown in Figure S2b. All $\Delta \mathrm{G}$ values were approximately $-20.0 \mathrm{kcal} /$ 
a
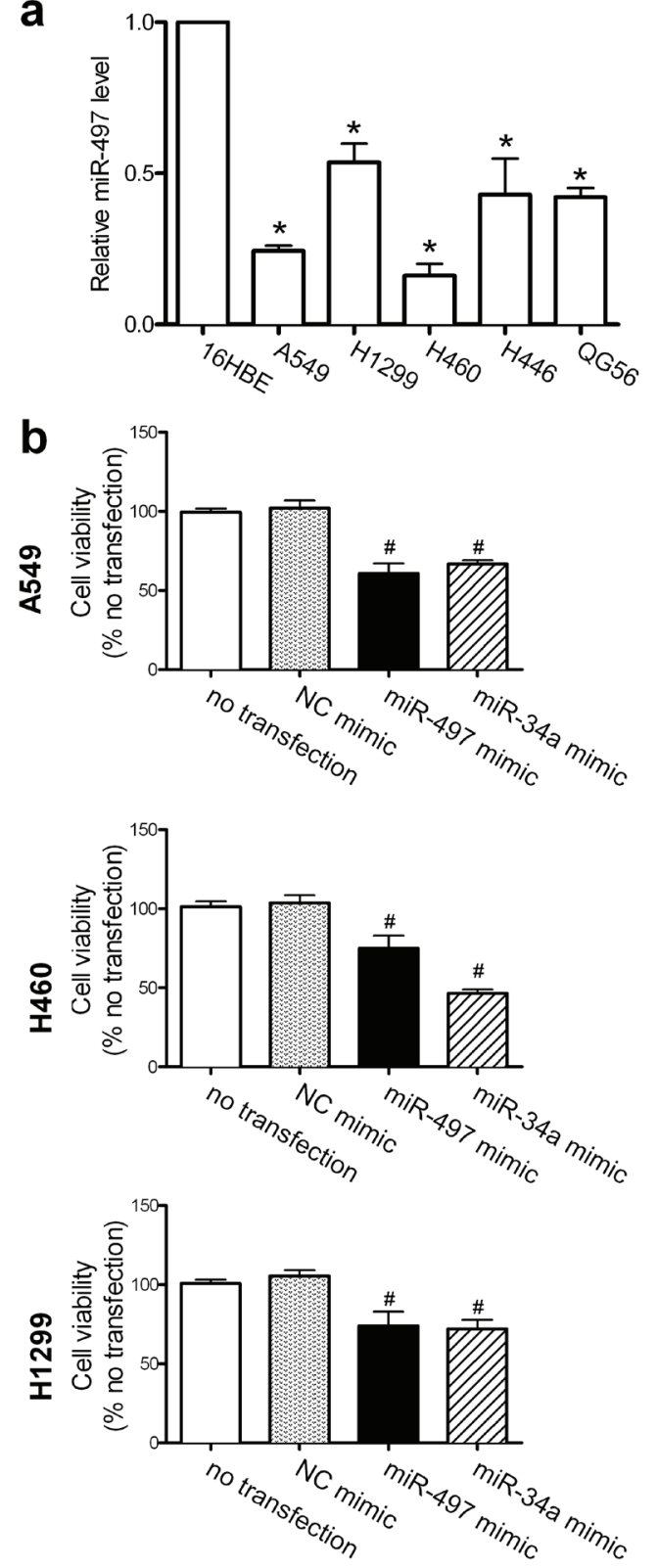

d

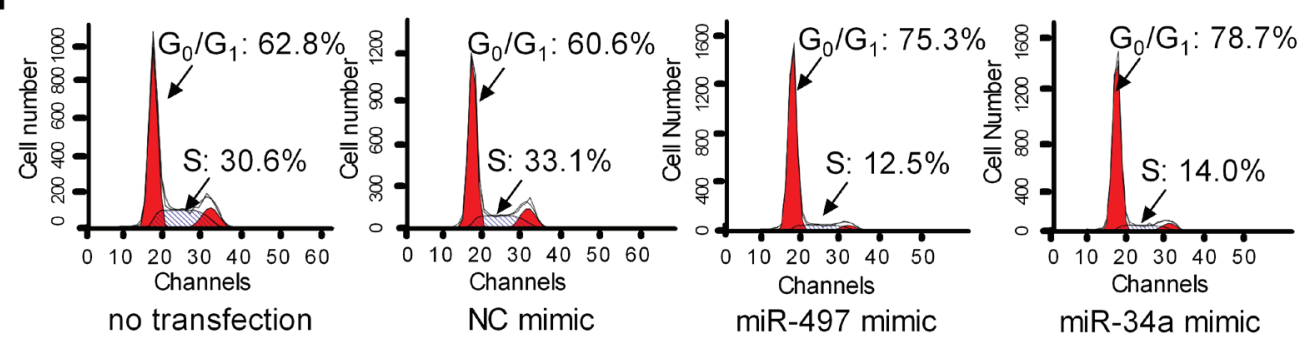

Figure 1: Elevated levels of miR-497 or miR-34a inhibit cell proliferation. (a) The relative levels of miR-497 and miR-34a were determined with the TaqMan ${ }^{\circledast}$ MicroRNA Assay and are expressed as fold change after normalization to the internal control, U6BsnRNA. Mean \pm SEM, $\mathrm{n}=3(* \mathrm{P}<0.05, \# \mathrm{P}<0.01$, all vs. $16 \mathrm{HBE}$ cells). (b) A549, H460, and $\mathrm{H} 1299$ cells were transfected as described in Methods, and cell growth was monitored at $48 \mathrm{~h}$ using the CCK-8 assay. Mean $\pm \mathrm{SD}, \mathrm{n}=3$ (\#P $<0.01$ vs. $\mathrm{NC}$ mimic). (c) A549, H460, and H1299 cells were transfected, harvested at $48 \mathrm{~h}$, and stained for cell cycle analysis on a FACSCalibur flow cytometer. Mean $\pm \mathrm{SD}, \mathrm{n}=3\left({ }^{*} \mathrm{P}<\right.$ $0.05, \# \mathrm{P}<0.01$, all vs. $\mathrm{NC}$ mimic). (d) Representative histograms show the elevated levels of miR-497 and miR-34a that induced G0/G1 cell-cycle arrest in A549 cells; the percentages of cells in G0/G1 phase and S phase are shown. 
a
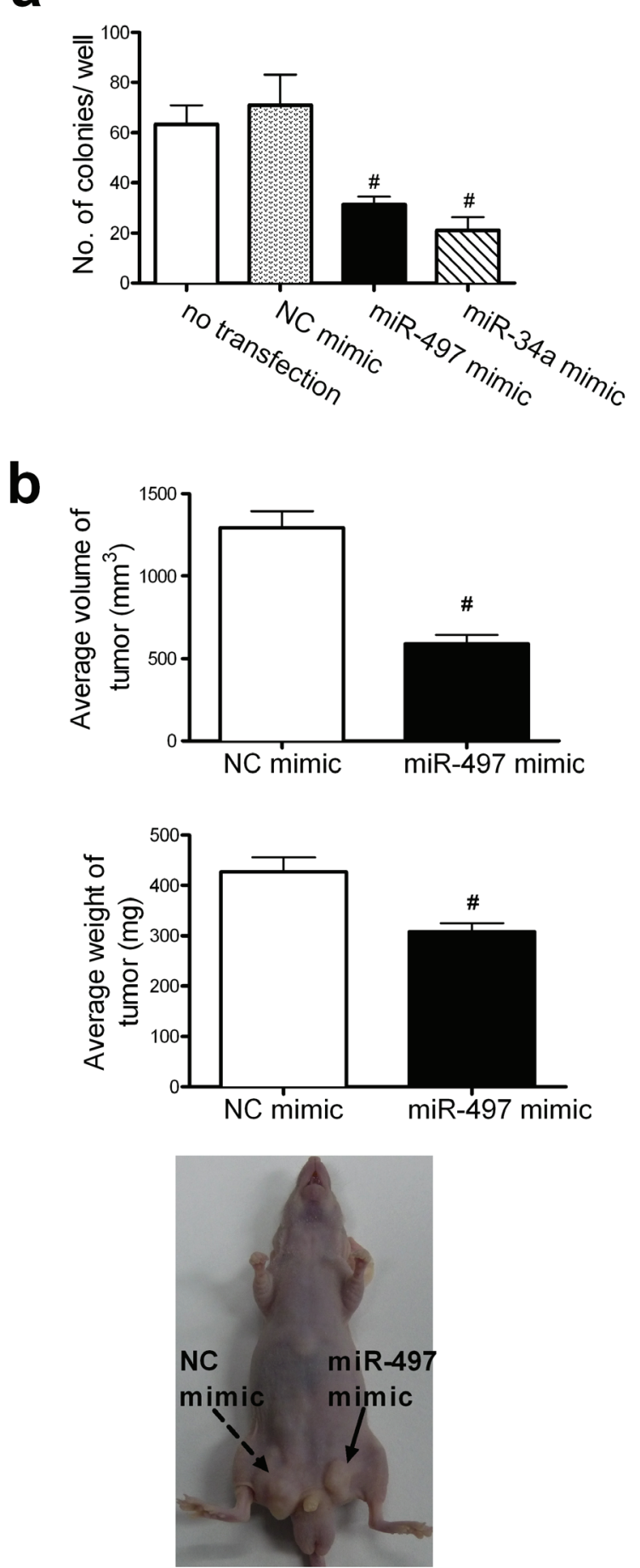
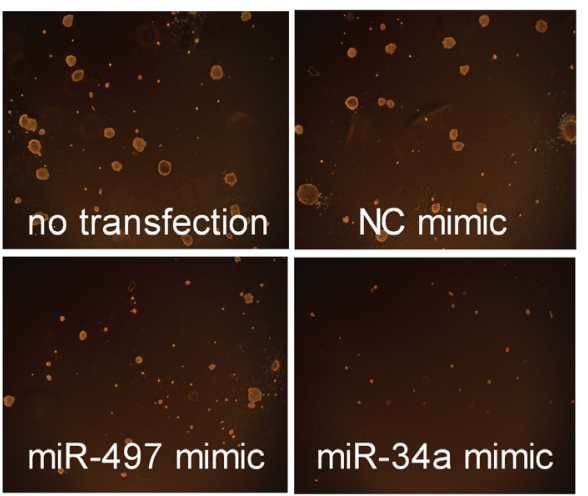

C
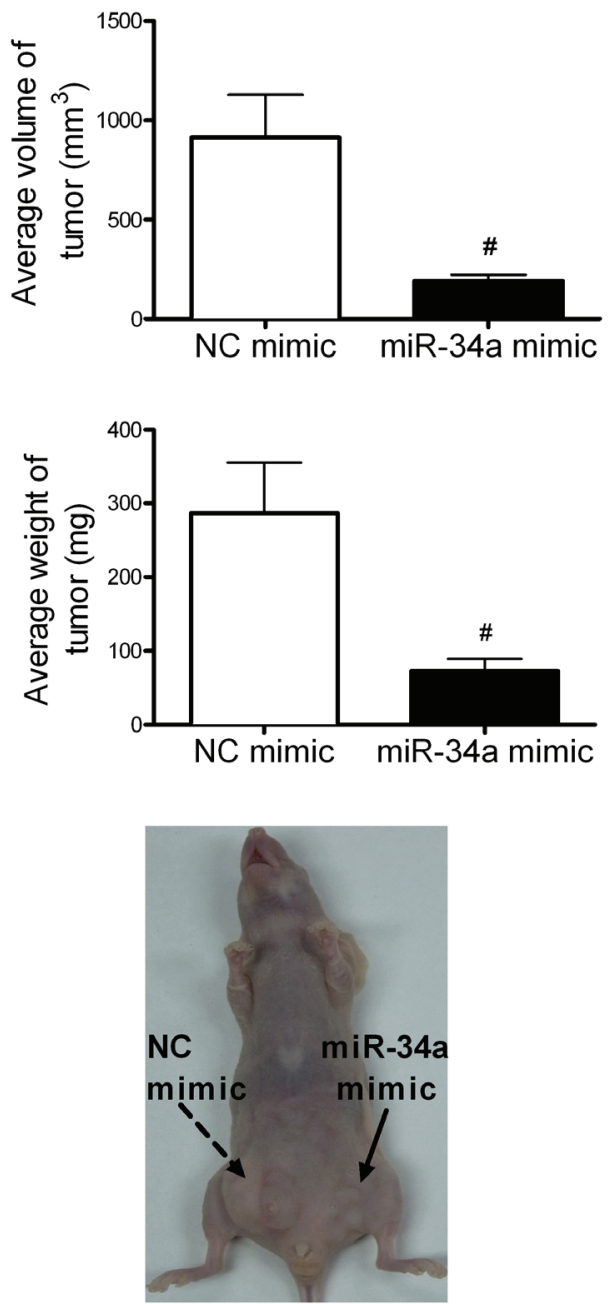

Figure 2: Elevated levels of miR-497 and miR-34a retard cell growth in vitro and in vivo. (a) Colony formation by A549 cells transfected with the miR-497 mimic or the miR-34a mimic was examined in soft agar. The number of colonies per well ( $\geq 50$ cells per colony) in triplicate wells is shown in the left column. Mean $\pm \mathrm{SD}(\# \mathrm{P}<0.01 \mathrm{vs}$. NC mimic). A representative result of the colonyformation assay is shown in the right column (original magnification, $\times 40$ ). The effects of miR-497 (b) or miR-34a (c) on tumor formation were examined in a nude mouse xenograft model. The bilateral inguinoabdominal flanks of nude mice were injected s.c. with NC-mimictransfected A549 cells (left flank) and miR-497-mimic-transfected A549 cells (right flank), or with NC-mimic transfected A549 cells (left flank) and miR-34a-mimic-transfected A549 cells (right flank). The miR-497-mimic-transfected or miR-34a-mimic-transfected cells generated tumors with smaller volumes and lower weights, as determined at necropsy, than those of tumors generated with NC-mimictransfected cells in the contralateral flanks. Mean $\pm \mathrm{SD}, \mathrm{n}=7$ ( $\# \mathrm{P}<0.01$, all vs. NC mimic). Photographs illustrating the features of tumor growth at necropsy are shown at the bottom of Fig. $2 \mathrm{~b}$ and $3 \mathrm{c}$. 
mol, which is considered authentic for miRNA targets. The miR-497 target sequences at nt 223-254 and nt 467-492 of the CCNE1 3-UTR are highly conserved among nine species (Figure S2c). One predicted target sequence for miR-34a was found at nt 226-255 (Figure S2d). Figure S2e shows the putative secondary RNA hybrid, with its $\Delta \mathrm{G}$. The miR-34a target sequence at nt 226-255 of the 3'UTR is highly conserved among nine species (Figure S2f). Although the sequence of the miR-34a seed region pairs with G:U complementarity at nt 247, 248, and 253 of the UTR, the seed regions of miR-497 (5'-AGCAGCA-3') and miR-34a (5'-GGCAGUG-3') are complementary to the same sequence at nt 247-253 (5'-UGCUGCU-3') in the UTR. Therefore, miR-497 and miR-34a share one binding site (nt 247-253) in the 3'-UTR of CCNE1.

\section{CCNE1 is a direct target of miR-497 and miR-34a}

To confirm that CCNE1 is targeted by miR-497 and miR-34a, we investigated the effects of miR-497 and miR-34a on cyclin E1 levels by immunoblotting. Overexpression of miR-497 or miR-34a in A549, H460, and H1299 lung cancer cells by transfection with miR497 or miR-34a mimics (Figure S3a and S3b) markedly reduced the levels of cyclin E1 protein (Figure 3a). However, real-time quantitative polymerase chain reaction (real-time qPCR) showed no changes in CCNE1 mRNA levels in response to $\mathrm{miR}-497$ or miR-34a upregulation (Figure S3c). This indicates that the negative correlation between cyclin E1 expression and miR-497 or miR-34a levels is due to post-transcriptional modulation of cyclin E1 expression.

The wild-type CCNE1 3'-UTR and a mutant CCNE1 3'-UTR were subcloned downstream from the Renilla luciferase gene in the psiCHECK2 vector to determine whether they bound directly to seed regions of the miRNAs. In Figure 3b, the wild-type sequence ( $\alpha$, wtCCNE), mutant sequences at nt 247-253 ( $\beta$, mt-CCNE $\beta$ ) or nt 485-491 ( $\gamma$, mt-CCNE $\gamma)$, and mutant sequences at both binding sites $(\delta, \mathrm{mt}-\mathrm{CCNE} \delta)$ in the $C C N E 13^{\prime}$-UTR were inserted individually into the vector, generating four plasmids as follows: wt-CCNE, mt-CCNE $\beta$, mt-CCNE $\gamma$, and mt-CCNE $\delta$. The binding sites between miR-34a and the wild-type or mutant $C C N E 1$ were examined (Figure $3 \mathrm{c})$. When the wt-CCNE plasmid was cotransfected with the miR-34a mimic, the luciferase activity of A549 cells was markedly reduced by $34.56 \pm 1.13 \%$ (Figure $3 \mathrm{~d}$ ). When the mt-CCNE $\beta$ plasmid was cotransfected with the miR-34a mimic or an inhibitor, the luciferase activity did not differ from that of the control. These data confirm that miR-34a directly targets CCNE1. To examine the interaction between miR-497 and CCNE1, the binding sites in CCNE1 were completely mutated, or mutated individually at each nucleotide (Figure 3e). When the wt-CCNE plasmid was cotransfected with the miR-497 mimic, the luciferase activity was markedly reduced by
$40.09 \pm 1.99 \%$ (Figure 3f). Moreover, when either plasmid (mt-CCNE $\beta$ or mt-CCNE $\gamma$ ) with only one mutant site was cotransfected with the miR-497 mimic, the luciferase activity was slightly reduced, whereas cotransfection of the mt-CCNE $\delta$ plasmid, which contained two completely mutated binding sites, with the miR-497 mimic reversed the miR-497 induced reduction of luciferase activity (Figure 3f). However, because the endogenous levels of miR-34a and miR-497 are low in A549 cells, transfection with miR-497 and miR-34a inhibitors did not affect the levels of luciferase activity (Figures $3 \mathrm{~d}$ and 1f).

\section{Cyclin E1 mediates the effects of miR-497 or miR- 34a on cell growth}

Because CCNE1 was identified as a direct target of miR-497 and miR-34a, we investigated whether the effects of miR-497 and miR-34a on cell proliferation were mediated by the modulation of CCNE1 expression. Cell proliferation and cell-cycle distribution were examined in A549 cells after CCNE1 knockdown and overexpression of the miRNAs. The efficiency of RNA interference was confirmed by real-time qPCR (Figure 4a, upper panel) and immunoblotting (Figure 4a, lower panel). Knockdown of CCNE1 significantly inhibited cell viability and $\mathrm{G}_{0}$ / $\mathrm{G}_{1}$ arrest in A549 cells, whereas miR-497 or miR-34a overexpression did not enhance the effect of CCNE1 knockdown (Figure $4 \mathrm{~b}$ and $4 \mathrm{c}$ ). A typical histogram of the cell cycle is shown in Figure 4c. These results support the assumption that the effects of miR-497 and miR-34a on cell growth are mediated by its modulation of CCNE1 expression.

\section{Synergistic effects of miR-497 and miR-34a on tumor growth retardation}

Because CCNE1 is a cotarget of miR-497 and miR-34a, we examined whether the two miRNAs exert synergistic effects on cell growth. First, expression plasmids transiently expressing miR-497 (Hi-miR497), miR-34a (Hi-miR-34a), and a plasmid coexpressing miR497 and miR-34a (Hi-miR497/34a) were constructed and verified by DNA sequencing and a TaqMan ${ }^{\circledR}$ MicroRNA Assay (Figure S4). The viability of cells transiently transfected with Hi-miR497, Hi-miR-34a, or HimiR497/34a was reduced at 48, 72, and 96 h. At 72 h, cell viability decreased from $2.28 \pm 0.17$ in the mock group to $1.73 \pm 0.17,1.58 \pm 0.09$, or $1.0 \pm 0.02$ in cells transfected with Hi-miR497, Hi-miR-34a, or Hi-miR497/34a, respectively, indicating that the Hi-miR497/34a plasmid caused a more marked reduction in cell viability than the Hi-miR497 or Hi-miR-34a plasmids (Figure 5a). The proliferation inhibition rate of Hi-miR497/34a (55.99\%) was almost the same as the total inhibition rate $(54.82 \%)$ of Hi-miR497 and Hi-miR-34a at 72 h. The colony 
a

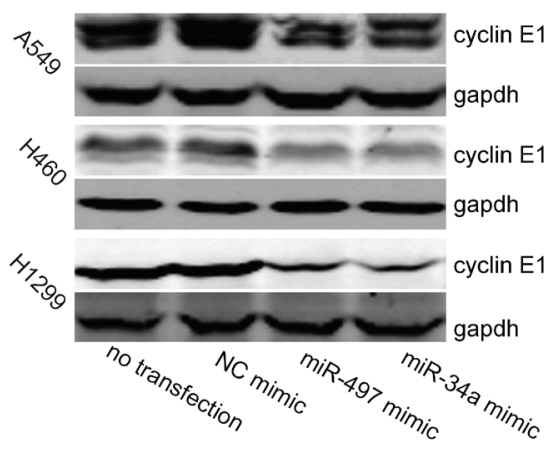

C

$$
\begin{array}{lc}
\text { wt-CCNE } & \text { 5'----UgCGUGCUCCCGAUGCUGCUA--3' } \\
\text { miR-34a } & \text { 3'---UgUUGGUCGAUUCU GUGACGG U--5' } \\
\text { mt-CCNE } \beta & \text { 5'-----UGCGUGCUCCCGAACGACGA A--3' }
\end{array}
$$

b

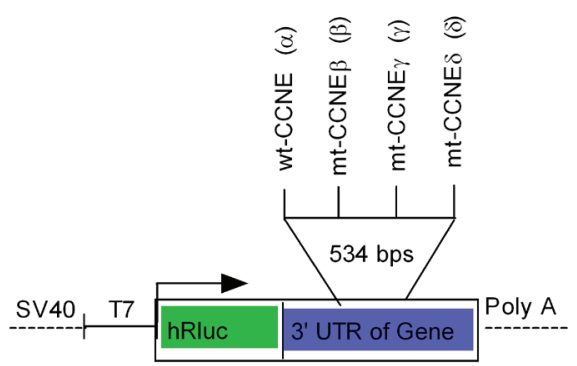

d

\begin{tabular}{|c|c|}
\hline $\begin{array}{l}\text { miR-497 } \\
\text { wt-CCNE }\end{array}$ & 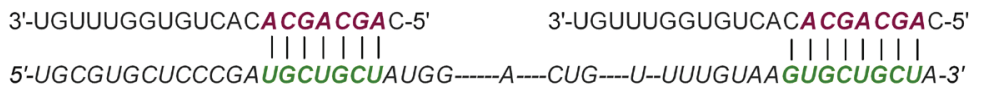 \\
\hline $\operatorname{miR}-497$ & 3'-UGUUUGGUGUCAC ACGACGA C-5' \\
\hline t-CCNE $\beta$ & 5'UGCGUGCUCCCGAACGACGAAUGG-----A--- -CUG----U-UUUGUAA \\
\hline $\operatorname{miR}-497$ & 3'-UGUUUGGUGUCAC ACGACGA C-5' \\
\hline mt-CCNE $\gamma$ & 5'UGCGUGCUCCCGAUGCUGCUAUGG----A----CUG---U-UUUGUAAGACGACGAA-3' \\
\hline miR-497 & 3'-UGUUUGGUGUCAC ACGACGA C-5' \\
\hline t-CCNE $\delta$ & 5'UGCGUGCUCCCGAACGACGAAUGG-----A----CUG---U--UUUGUAAGACGACGAA-3' \\
\hline
\end{tabular}

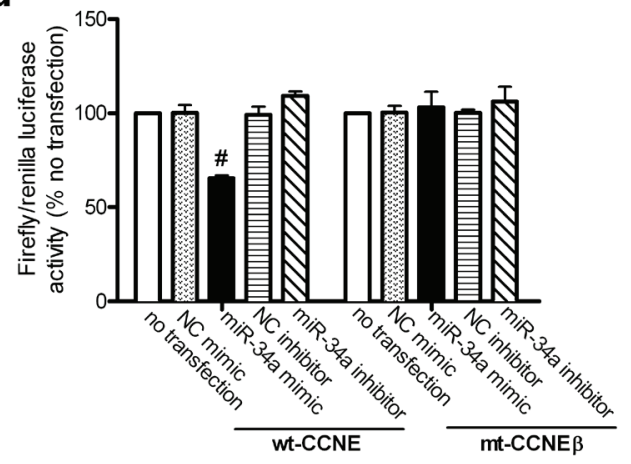

e

f

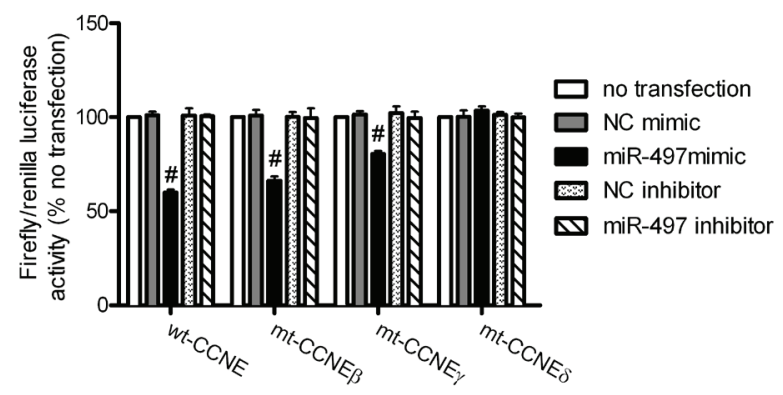

Figure 3: CCNE1 is a direct target of miR-497 and miR-34a. (a) The expression levels of the cyclin E1 protein were measured by immunoblotting using GAPDH as the loading control. Experiments were performed in triplicate, with results similar to those shown. (b) Diagram of the psiCHECK2 vector used for the luciferase reporter activity assay. The arrow indicates the transcription start site. The magnified panel shows the location of the wild-type CCNE1 3'-UTR ( $\alpha$, wt-CCNE) or mutant CCNE1 3'-UTR at nt 247-253 ( $\beta$, mt-CCNE $\beta)$, at nt 483-490 ( $\gamma, \mathrm{mt}-\mathrm{CCNE} \gamma)$, and at both $(\delta, \mathrm{mt}-\mathrm{CCNE} \delta)$, which were subcloned into the psiCHECK2 vector. Thus, four individual plasmids were generated: wt-CCNE, mt-CCNE $\beta$, mt-CCNE $\gamma$, and mt-CCNE $\delta$. (c) Diagram of the wt-CCNE and mt-CCNE $\beta$ reporter constructs. mt-CCNE $\beta$ contains a seven-base mutation in the miR-34a target region, abolishing its binding to miR-34a. (d) Firefly luciferase reporter activity assay. The relative luciferase activity was normalized to the Renilla luciferase activity and compared with that in the no-transfection control. Mean $\pm \mathrm{SD}, \mathrm{n}=3$ (\#P $<0.01$ vs. NC mimic). (e) Outline of the wt-CCNE, mt-CCNE $\beta, \mathrm{mt}-\mathrm{CCNE} \gamma$, and mtCCNE $\delta$ reporter constructs. mt-CCNE $\beta$ and mt-CCNE $\gamma$ each contain one seven-base mutation in the miR-497 target region (at nt 247-253 or nt 483-490, respectively, in the CCNE1 3'-UTR), partly abolishing their binding to miR-497. mt-CCNE $\delta$ contains two seven-base mutations in the miR-497 target regions (at nt 247-253 and nt 483-490 of the CCNE1 3'-UTR), completely abolishing its binding to miR497. (f) Firefly luciferase reporter activity assay. Relative luciferase activity was normalized to the Renilla luciferase activity and compared with that in the no-transfection control. Mean $\pm \mathrm{SD}, \mathrm{n}=3$ ( $\# \mathrm{P}<0.01$, all vs. $\mathrm{NC}$ mimic). 
a
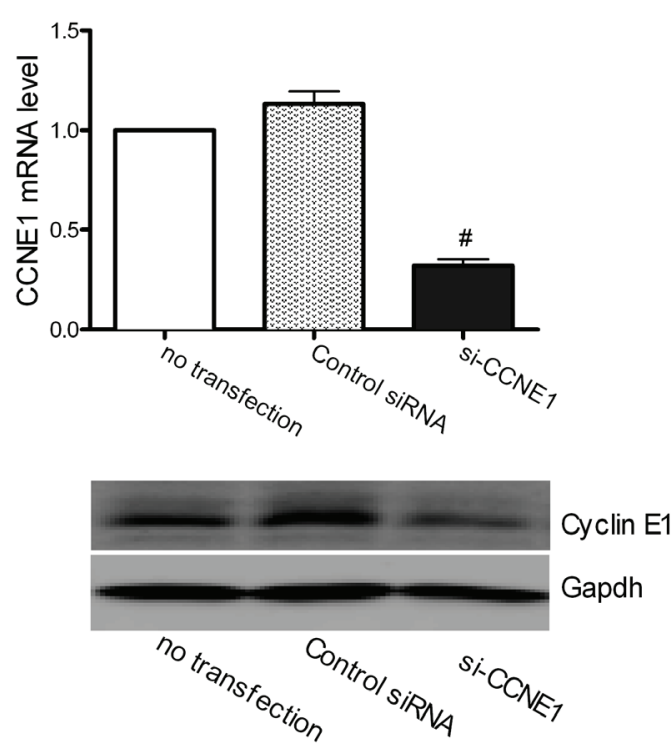

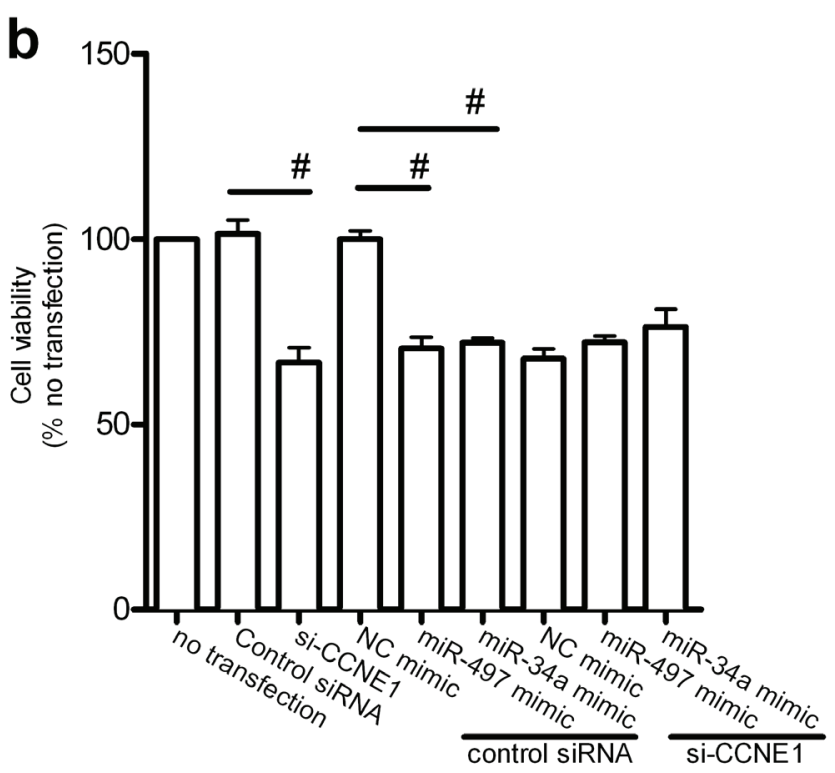

C
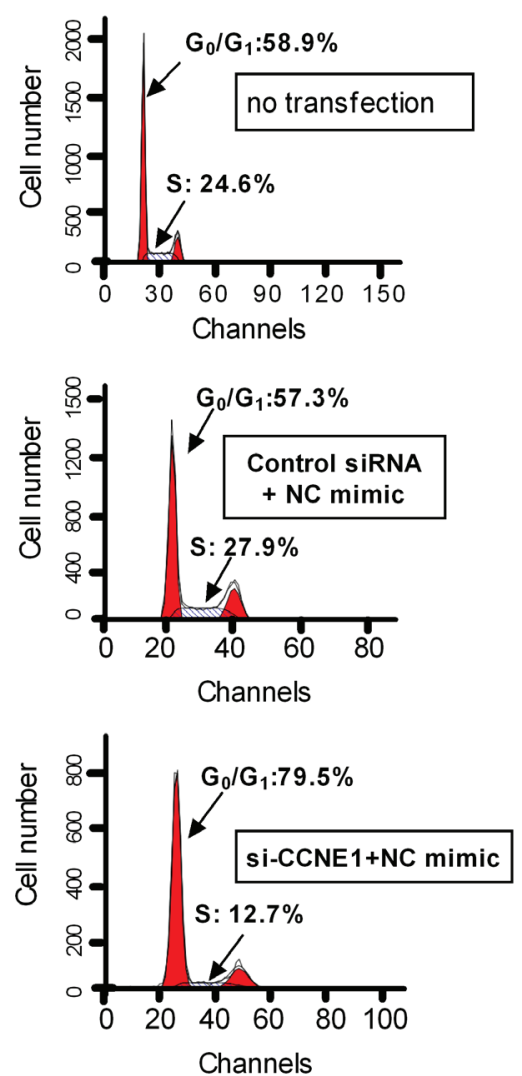
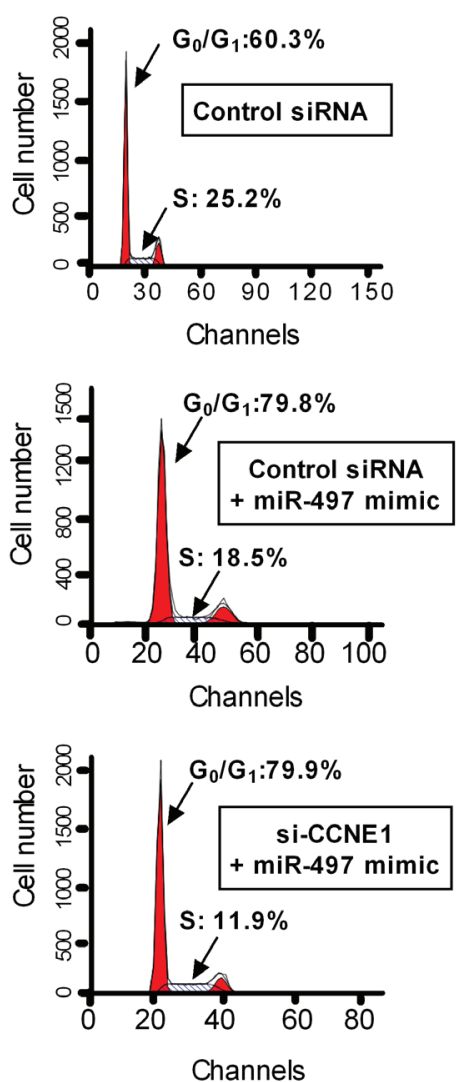
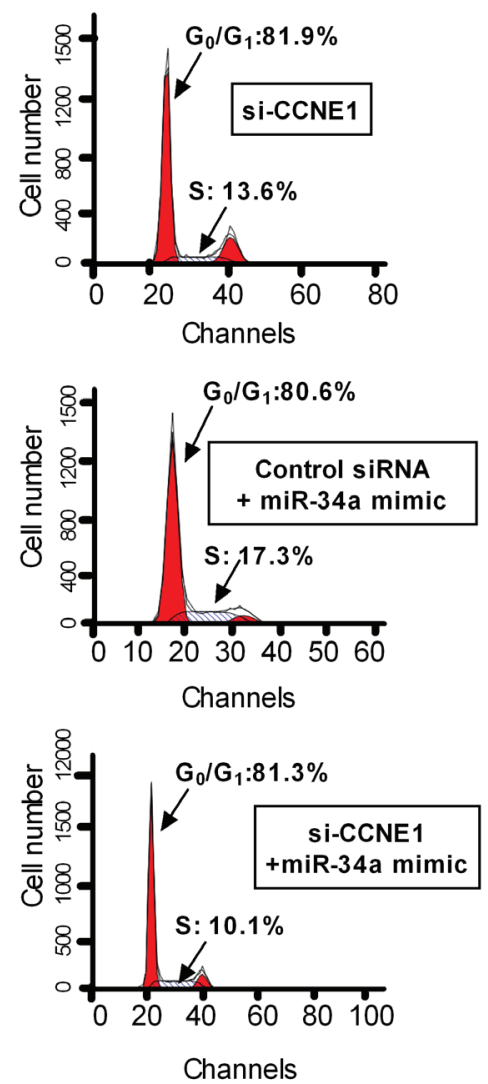

Figure 4: CCNE1 knockdown affected the miR-497 and miR-34a induced inhibition of proliferation. (a) Validation of siRNA-mediated CCNE1 silencing in A549 cells. The relative CCNE1 mRNA levels, as determined by real-time qPCR, are expressed as fold changes after normalization to the internal control (18S rRNA) (upper row). Mean $\pm \mathrm{SEM}, \mathrm{n}=3$ (\#P $<0.01$ vs. control siRNA). GAPDH was used as the loading control for immunoblotting to determine the cyclin E1 protein levels. A representative result from three independent experiments is shown (bottom row). (b) Cell growth was monitored in A549 cells using the CCK-8 assay. Mean \pm SD, $n=3$ (\#P $<0.01$, CCNE1 siRNA vs. control siRNA, control siRNA + miR-497 mimic vs. control siRNA + NC mimic, control siRNA + miR-34a mimic vs. control siRNA + NC mimic). (c) Cell-cycle distribution of G0/G1 phase in A549 cells was analyzed with a FACSCalibur flow cytometer. Representative histograms show the percentages of cells in the G0/G1 and S phases. 
formation rate of cells transiently transfected with $\mathrm{Hi}$ miR497, Hi-miR-34a, or Hi-miR497/34a decreased by $36.84 \pm 7.02 \%, 41.23 \pm 4.09 \%$, or $64.04 \pm 2.92 \%$ (Figure 5b). Cells transfected with miR-497/miR-34a formed fewer and smaller colonies than cells transfected with Hi-miR-34a or Hi-miR497 alone. A549 cells transiently transfected with mock (empty plasmid), Hi-miR497, HimiR34a, or Hi-miR497/34a were inoculated s.c. into the bilateral inguino-abdominal flanks of nude mice. The average volume of tumors expressing Hi-miR497 (149.40 $\left.\pm 17.84 \mathrm{~mm}^{3}\right)$, Hi-miR-34a $\left(190.80 \pm 19.36 \mathrm{~mm}^{3}\right)$, or HimiR497/34a $\left(39.60 \pm 14.32 \mathrm{~mm}^{3}\right)$ was lower than that of the mock group $\left(458.20 \pm 30.64 \mathrm{~mm}^{3}\right)$ (Figure $\left.5 \mathrm{c}\right)$. The average weight of tumors expressing Hi-miR497 (456.00 $\pm 27.20 \mathrm{mg})$, Hi-miR-34a (554.00 $\pm 28.80 \mathrm{mg})$, or HimiR497/34a $(184.00 \pm 28.80)$ was lower than that of the mock group $(750.00 \pm 40.00 \mathrm{mg}$ ) after 5 weeks (Figure $5 \mathrm{~d})$. This indicated that the average volume and average weight of tumors transfected with Hi-miR497/34a were
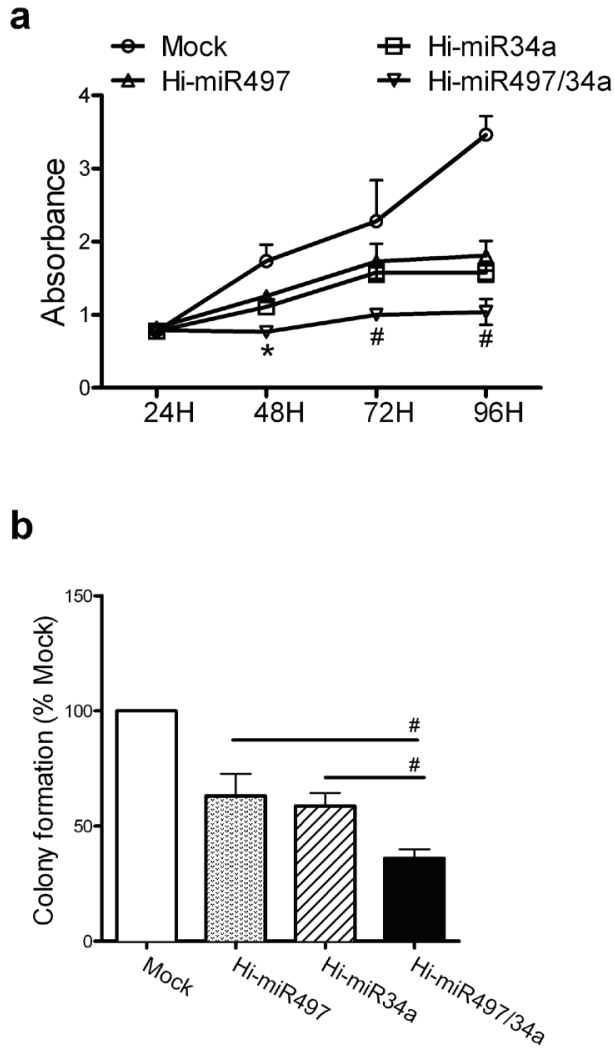

lower than those in the other groups after 5 weeks. Figure 5e illustrates the features of tumor growth. The tumor weight inhibition rate of Hi-miR497/34a (75.47\%) was greater than the total inhibition rate $(65.33 \%)$ induced by Hi-miR497 and Hi-miR-34a, whereas the tumor volume inhibition rate of Hi-miR497/34a was comparable to the total inhibition rate of Hi-miR497 and Hi-miR-34a. Taken together, these data indicate that miR-497 and miR-34a cooperate in inhibiting tumor growth.

\section{Synergistic effects of miR-497 and miR-34a on cotargeting $\mathrm{CCNE} 1$}

A549 cells stably expressing cyclin E1 (designated Hi-CCNE1a) were generated (Figure S5). Hi-CCNE1-a cells transfected with $\mathrm{Hi}$-miR497/34a expressed lower levels of cyclin E1 protein than those transfected with HimiR497 or Hi-miR34a (Figure 6a). This suggests that the

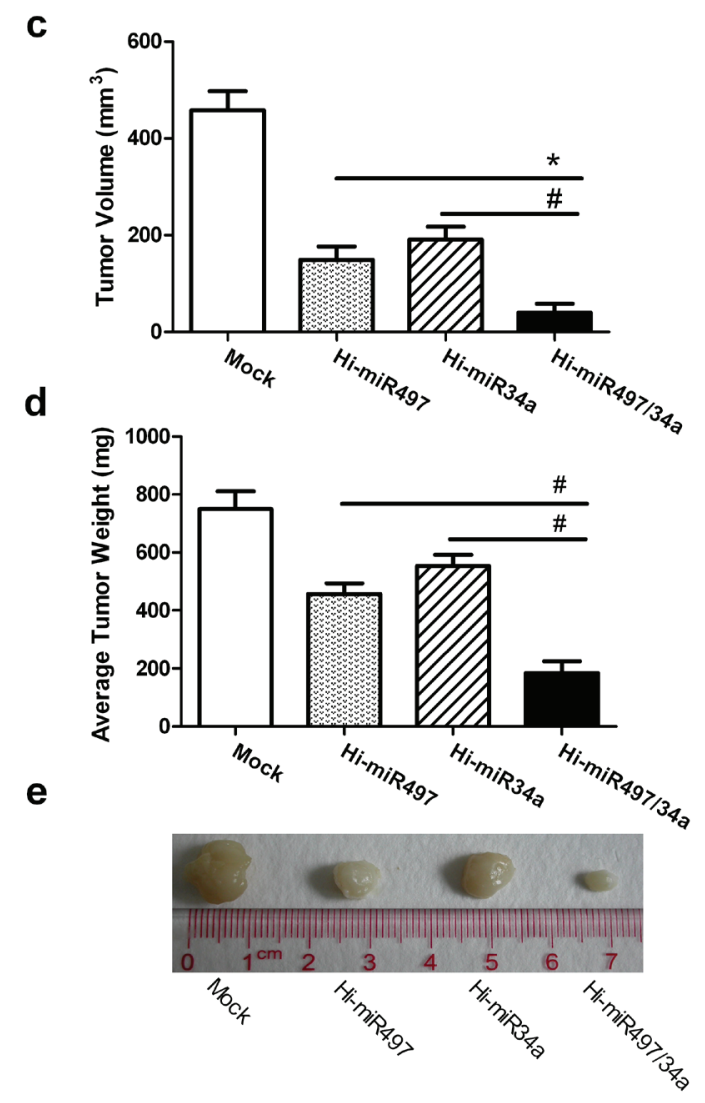

Figure 5: miR-497 and miR-34a synergistically retard cell growth. (a) The cell-growth curves for A549 cells transfected with Hi-miR497, Hi-miR-34a, or Hi-miR497/34a at 24, 48, 72, and 96 h. Means \pm SD, n $=3(* \mathrm{P}<0.05$, at 48 h, Hi-miR497/34a vs. HimiR497; \#P < 0.01, at 72 and 96 h, Hi-miR497/34a vs. Hi-miR497 or Hi-miR34a). (b) A549 cells were transfected with Hi-miR497, HimiR34a, or Hi-miR497/34a. Colony formation was examined in soft agar. Numbers of colonies per well ( $\geq 50$ cells per colony) in triplicate wells are shown. Mean \pm SD (\#P $<0.01$, Hi-miR497/34a vs. Hi-miR497, Hi-miR497/34a vs. Hi-miR34a). The cooperative effects of miR-497 and miR-34a on tumor formation were examined in a nude mouse xenograft model. Hi-miR497/34a-transfected A549 cells were injected s.c. into the right inguino-abdominal flanks of nude mice. The Hi-miR497/34a-transfected cell treatment generated tumors with smaller volumes (c) and lower tumor weights (d), as determined at necropsy, than those of tumors generated with mock-transfected cells. Mean $\pm \mathrm{SD}, \mathrm{n}=5$ (\#P < 0.01, Hi-miR497/34a vs. Hi-miR497, Hi-miR497/34a vs. Hi-miR34a). (e) Images show the features of tumor growth at necropsy. 
coexpression of miR-497 and miR-34a enhanced the effect of each individual miRNA on the modulation of cyclin E1 expression. A reporter gene activity assay was used to test this hypothesis in A549 cells. Cotransfection of the wt-CCNE plasmid with Hi-miR497/34a reduced luciferase activity to a greater extent than cotransfection of wtCCNE with Hi-miR497 or Hi-miR34a alone (Figure 6b). However, when the mt-CCNE $\delta$ plasmid was cotransfected with Hi-miR497/34a, the luciferase activity did not differ from that of cells cotransfected with either Hi-miR497 or Hi-miR34a alone (Figure 6b). This suggests that the synergistic effects of miR-497 and miR-34a are correlated with the levels of cyclin E1. Transfection of Hi-CCNE1a cells with Hi-miR-497/34a did not affect colony formation (Figure 6c) compared with that of cells transfected with either Hi-miR497 or Hi-miR34a, as shown in Figure 6d. Therefore, overexpression of CCNE1 abolished the growth retardation induced by miR497 and miR34a in A549 cells, and CCNE1 mediates the synergistic effects of miR-497 and $\mathrm{miR}-34 \mathrm{a}$.
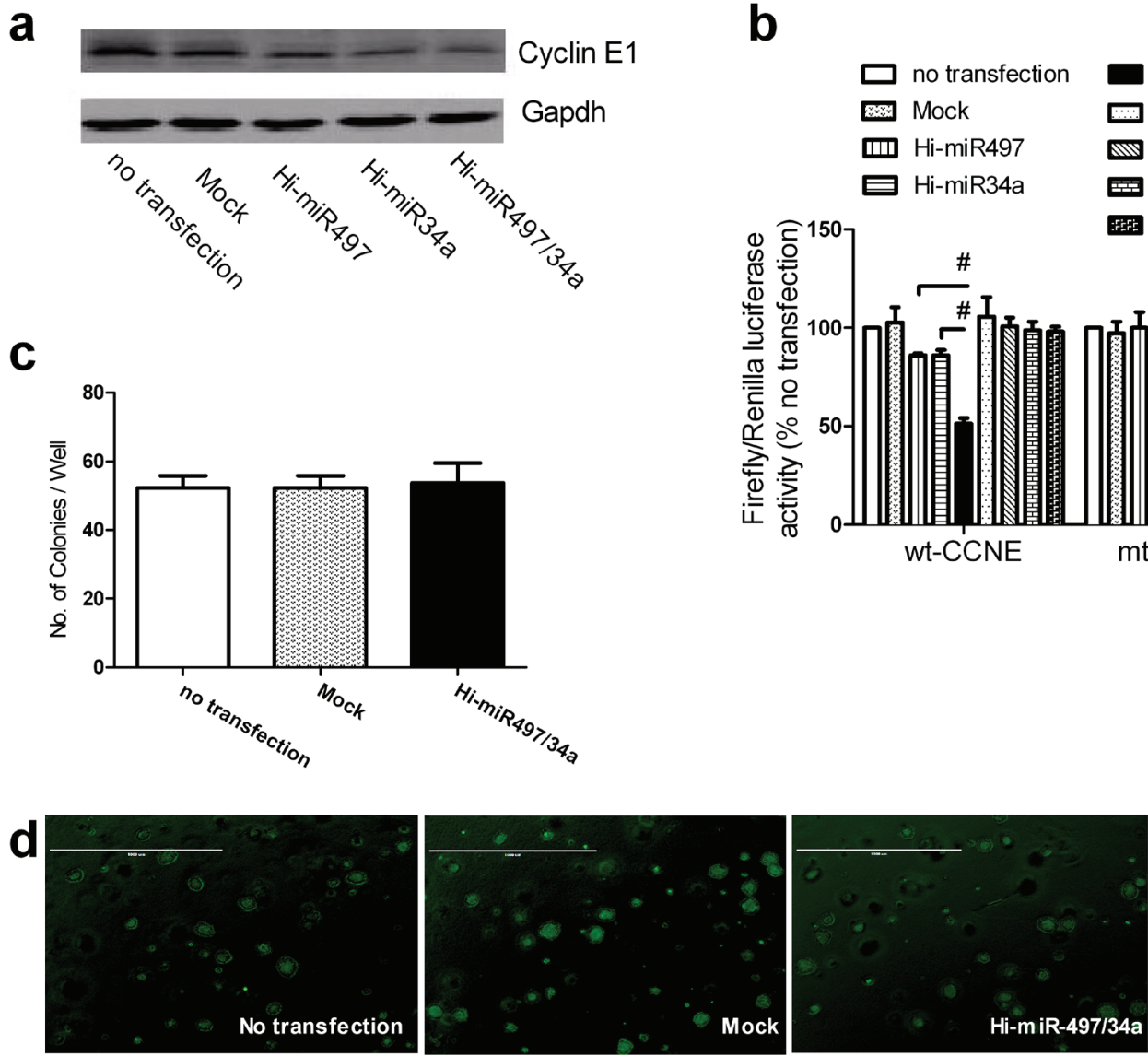

Figure 6: miR-497 and miR-34a act synergistically by cotargeting CCNE1. (a) Cyclin E1 protein levels in individually transfected A549 cells. Cyclin E1 protein levels were determined by immunoblotting using GAPDH as the loading control. A representative result of three independent experiments is shown. (b) Firefly luciferase reporter activity assay. A549 cells were transfected with Hi-miR497, Hi-miR34a, Hi-miR497/34a, or inhibitors. The relative luciferase activity was normalized to the Renilla luciferase activity and compared with that of the untransfected control. Mean $\pm \mathrm{SD}, \mathrm{n}=3$ (\#P $<0.01 \mathrm{Hi}-\mathrm{miR} 497 / 34 \mathrm{a}$ vs. Hi-miR497 or Hi-miR34a). (c) Hi-CCNE1a cells were transfected with empty vector or Hi-miR497/34a. Colony formation was examined in soft agar. (d) A representative result of the colony formation assay is shown (original magnification, $\times 40$ ). 
cells. This prompted us to investigate whether these two miRNAs function as antitumor agents. Some miRNAs that are downregulated in cancer are found in regions with frequent loss of heterozygosity [30]. miRNA-497 and miRNA-34a are located on chromosomes $17 \mathrm{p} 13.1$ and $1 \mathrm{p} 36$, respectively. The loss or deletion of chromosome $17 \mathrm{p} 13.1$ or $1 \mathrm{p} 36$ has been reported in various types of cancer, including lung cancer [31, 32], suggesting that the downregulation of miRNA-497 or miRNA-34a in these cancers arises from genomic DNA loss or deletion. miR$34 \mathrm{a}$, located at $1 \mathrm{p} 36$, has been extensively studied as a microtumor suppressor $[33,34]$, and miR-497, located at $17 \mathrm{p} 13.1$, is deleted in $93 \%$ of small-cell lung cancers [35]. Son et al. reported that miR-497 is downregulated in lung cancer [25]; however, its role in lung cancer remains unclear. Here, we studied the function of miR-497 in lung cancer cells, and showed that miR-497 and miR34 a inhibit cell growth in vitro and in vivo, supporting our hypothesis that the two miRNAs function as tumor suppressors. Several studies have reported that miR-497 and miR-34a are potential anticancer agents based on their ability to target oncogenes [24, 25, 36, 37]. In the present study, we found that they cotarget $C C N E 1$, repressing the expression of cyclin E1.

Cyclin E1 is an essential regulator of cell cycle $G_{1}$ progression and entry into $\mathrm{S}$ phase. It is a nuclear protein that was first identified by its ability to complement the proliferative defects of cyclin-deficient yeast cells. It is overexpressed in various cancers, including lung, breast, and gastrointestinal tract tumors [38-40]. Several mechanisms regulate its expression in tumors. Although gene amplification might be involved, the expression of cyclin E1 is also modulated post-transcriptionally by miRNAs. Cyclin E1 (or cyclin E) is repressed by miR$15 \mathrm{~b}$, miR-16, miR-34c, and miR-145 [41, 42] in other cancer cells. In the present study, we showed for the first time that both miR-34a and miR-497 bind to the 3'-UTR region of CCNE1, as confirmed by immunoblotting and luciferase activity assays. Previous studies showed that miR-34a targets the oncogenes CDK4, CDK6, CCND1, $M E T$, and BCL2 [36, 43, 44], whereas miR-497 targets the oncogenes $C C N D 2$ and $B C L 2[37,45]$ in various types of cancer. These and our results, together with the strong possibility that more miR-497 or miR-34a targets will be discovered soon, suggest that these two miRNAs regulate proliferation-related mRNAs (including CCNE1), and thus function as tumor suppressors.

The protein encoded by $C C N E 1$, a newly identified cotarget for miR-34a and miR-497, plays a key role in regulating the growth of lung cancer cells, and its effect is mediated by the cooperative action of the two miRNAs. Several studies have focused on the effects of the miRNA family axis on cancer because many miRNAs contain the same 7-nt or 8-nt seed sequence. Most single miRNA mutations do not markedly affect the corresponding phenotype, whereas knocking out multiple or all miRNA family members can affect several phenotypes in insects $[46,47]$. This phenomenon, which reflects the complexity of miRNAs and especially the miRNA-miRNA network, allows them to perform many biological functions. Here, we found that two miRNAs from different families synergistically inhibit the growth of lung cancer cells, which indicates that the two miRNA families share similar biological functions. Biochemical and bioinformatics studies showed that the 5' ends of miRNAs, designated as "seed sequences", play critical roles in target recognition and posttranscriptional repression $[3,48$, 49]. The recognition is based on the complementary base paring between the seed sequence and the target mRNA. Studies have shown that G:U base pairing is tolerated in seed complementarity $[3,50]$. Therefore, miR-497 and miR-34a, with seed sequences 5'-AGCAGCA-3' and 5'-GGCAGUG-3', respectively, can bind to the same sequence (3'-UCGUCGU-5') in the 3' UTR of CCNE1; however, there are three-base variations between their seed regions. This was verified in our luciferase activity assay. Our results indicated that miR-497 and miR-34a synergistically inhibit cell proliferation, predominantly by repressing the expression of their cotarget, CCNE1. However, the relationship between miR-497 and miR-34a is complex and requires further research.

Activation of cyclin E:Cdk2 results in retinoblastoma tumor-suppressor gene (RB) inactivation by hyper-phosphorylation, induction of E2F target gene transcription, and cell cycle G1/S transition [18]. Cell cycle dysregulation (including the overexpression of cyclins) occurs frequently in neoplasia or cancer. Multiple reports suggested that cyclin E is a promising therapeutic target in lung [20,51], ovarian [52], and breast cancers [53, 54]. Li et al [53] showed that cyclin E siRNA delivered by intratumoral injection effectively inhibits cyclin E expression in vivo and results in tumor suppression. However, there are limitations to the therapeutic application of siRNAs, such as their stability, off-target side effects, and interferon responses to foreign nucleic acids. Unlike siRNAs targeting a single molecule, the miRNA approach might have a greater potential as cancer therapeutics because of the endogenous nature of miRNAs and their capacity to simultaneously regulate many different oncogenes across multiple pathways. Furthermore, evidence indicates that a combination of two tumor-suppressive miRNAs is superior to single miRNAs for the repression of oncogene expression, the inhibition of proliferation and invasion of cancer cells in culture, and the inhibition of tumor proliferation in vivo. Our data indicated that the tumor-suppressive miR-34a and miR497 could co-inhibit cyclin E1, suggesting that cyclin E1 is a key target mediating the anti-tumor effect of miR-34a and miR-497 in lung cancer. Both miRNAs modulate other oncogenic genes that may mediate their tumor suppressor function. Chek1 (putative target of miR-497 identified by the algorithm DIANA miRPath v.2.0), cdc25a (miR- 
497) [55], and cdk6 (miR-497and miR-34a) [55, 56] are involved in the indirect or direct regulation of the cyclin E1 downstream genes cdk2, RB and E2f3 (target for miR$34 \mathrm{a},[33,57])$. Therefore, the combination of miR-34a and miR-497 could be superior to each individual miRNA in its ability to retard lung cancer cell growth to some extent.

In conclusion, we showed that miR-497 and miR$34 \mathrm{a}$ act cooperatively to regulate certain aspects of tumorigenesis, including the growth of lung cancer cell lines, especially through their cooperative effect on the downregulation of cyclin E1 expression.

\section{MATERIALS AND METHODS}

\section{Cell culture and reagents}

The lung cancer cell lines A549, H1299, H460, H446, and QG56, purchased from the Chinese Academy of Sciences Cell Bank of Type Culture Collection (Shanghai, China), were cultured in RPMI-1640 medium (Invitrogen, Carlsbad, CA) supplemented with 10\% fetal bovine serum (FBS; Sijiqing Co., Ltd, Hangzhou, China). Normal human bronchial epithelial cells (16HBE), kindly provided by Dr. Xujun from the Guangzhou Institute of Respiratory Diseases, were maintained in minimum essential medium supplemented with 10\% FBS (Sijiqing Co., Ltd). All cells were incubated at $37^{\circ} \mathrm{C}$ in a humidified atmosphere of $5 \% \mathrm{CO}_{2}$. Antibody directed against cyclin E1 (Santa Cruz Biotechnology, Santa Cruz, CA), Alexa-Fluor-680conjugated goat anti-mouse IgG antibody (Molecular Probes, Invitrogen), and IRDye 800-conjugated anti-rabbit IgG antibody (Li-Cor, Lincoln, NE) were purchased for immunoblotting.

\section{Transient transfection of miRNAs or small interfering RNA (siRNA) oligonucleotides}

The oligonucleotides including miRNA mimics, inhibitors, and their negative control oligos were purchased from GenePharma (Shanghai, China). Cells were transiently transfected with $50 \mathrm{nM}$ miR-497 mimic, miR-34a mimic, miR-497 inhibitor, miR-34a inhibitor, CCNE1 siRNA (Qiagen, Germany), or siRNA negative control (NC siRNA; Qiagen) using Lipofectamine 2000 (Invitrogen).

\section{RNA extraction and real-time qPCR}

Total RNA was extracted with the TRIzol Reagent (Invitrogen). miRNA expression was analyzed using the TaqMan ${ }^{\circledR}$ MicroRNA Assay (Ambion, Austin, TX), which detects mature miRNAs, on the ABI 7500 Real-Time PCR System (Applied Biosystems, Foster City, CA), according to the manufacturer's protocol. Real-time qPCR was used to confirm the expression levels of mRNAs. cDNA was produced according to the protocol for PrimeScript $\mathrm{t}^{\mathrm{TM}}$ RT Reagent (TaKaRa, Japan), and real-time qPCR was performed as described in the method for SYBR ${ }^{\circledR}$ Premix Ex Taq ${ }^{\mathrm{TM}}$ II (TaKaRa) with the Rotor-Gene 6000 ${ }^{\mathrm{TM}}$ (Corbett Research), supplied with analytical software. 18S rRNA was used for normalization. The oligonucleotides used as PCR primers were as follows: CCNE1 (forward) 5'-CGTGGCCTCTAAGATGAAGG-3', CCNE1 (reverse) 5'-CTGGCATTTTGGAGAGGAAG-3'; $18 \mathrm{~S}$ rRNA (forward) 5'-TCAGTGGTGGACCTGACCTG-3', 18S rRNA (reverse) 5'-TGCTGTAGCCAAATTCGTTG-3'.

\section{Immunoblotting analysis}

Total cell lysates were prepared with cell lysis buffer (CST, Beverly, MA) containing proteinase inhibitors ( $1 \%$ cocktail and $1 \mathrm{mmol} / \mathrm{L}$ PMSF, both from Kangcheng, China). Cell proteins $(50 \mu \mathrm{g})$ were separated by $12 \%$ SDS-PAGE and transferred to PVDF membranes (Millipore, Bedford, MA). The membranes were blocked, incubated with anti-cyclin E1 or anti-glyceraldehyde phosphate dehydrogenase (GAPDH) antibody, and then with secondary antibodies. Immunoblotting analyses were performed with the Odyssey Infrared Imaging System (LiCor).

\section{Luciferase assays}

The sequences of the CCNE1 3'-UTR and the CCNE1 3-UTRs in which the putative binding sites had been mutated were amplified with specific primers (listed in Table S1), and verified by DNA sequencing. These gene fragments were then subcloned downstream from the Renilla luciferase gene in the psiCHECK2 vector (Promega, Madison, WI) to generate the wildtype CCNE1 plasmid (wt-CCNE), the partial mutant $C C N E 1$ plasmids (mt-CCNE $\beta$ and $\mathrm{mt}-\mathrm{CCNE} \gamma$ ), and the complete mutant CCNE1 plasmid (mt-CCNES). For luciferase assays, A549 cells were transfected with wtCCNE, mt-CCNE $\beta$, mt-CCNE $\gamma$, or mt-CCNE $\delta$ in 24well plates using Lipofectamine 2000 (Invitrogen). The transfection mixtures contained $100 \mathrm{ng}$ of plasmid and 50 nM synthetic mimic, inhibitor, Hi-miR497, Hi-miR34a, or Hi-miR497/34a. A549 cells were also transfected with the psiCHECK-2 vector as the normalization control. The cells were collected $48 \mathrm{~h}$ after transfection, and the luciferase activity was measured with the Dual-Luciferase Reporter Assay System (Promega). 


\section{Cell viability and cell-cycle assays}

For the cell viability assay, cells were incubated in 10\% Cell Counting Kit-8 (CCK-8; Dojindo, Japan), diluted in normal culture medium, at $37^{\circ} \mathrm{C}$ for $2 \mathrm{~h}$ and the absorbance at $490 \mathrm{~nm} /$ absorbance at $650 \mathrm{~nm}\left(\mathrm{~A}_{490 / 650}\right)$ ratio was calculated. For cell-cycle analysis, cells were washed twice with PBS, collected, fixed, stained with propidium iodide (Sigma, St Louis, MO), and analyzed with fluorescence-activated cell sorting (FACS) on a FACSCalibur flow cytometer (Becton Dickinson, Mountain View, CA). Cell viability and cell-cycle distribution were determined $48 \mathrm{~h}$ after transfection.

\section{Soft-agar colony formation}

Transfected cells were propagated on soft agar. A base layer $(1.5 \mathrm{~mL})$ of agar (Amresco, Solon, $\mathrm{OH}$ ) ( $0.6 \%$ agar in RPMI-1640 with $10 \%$ FBS) was allowed to solidify in a six-well flat-bottomed plate before the addition of $2 \mathrm{~mL}$ of a cell suspension containing 2000 cells in $0.3 \%$ agar in RPMI- 1640 with $10 \%$ FBS. The colonies were allowed to grow for 28 days at $37^{\circ} \mathrm{C}$ under $5 \% \mathrm{CO}_{2}$ and visualized with an inverted microscope (Olympus IX71, Olympus, Tokyo, Japan).

\section{Tumor xenograft model}

Five-week-old male nude mice (BALB/c nu/ nu), purchased from the Medical Animal Experimental Center of Guangdong Province, were used to examine the tumorigenicity of the transfected cells. The animal protocol was approved by the Animal Care and Use Committee. The transfected cells were propagated and $5 \times 10^{6}$ cells were inoculated s.c. into the dorsal flanks of the mice. Tumor size was measured weekly and tumor volume was estimated as described in our previous report [17]. Tumors were removed and weighed 5 weeks after the injection of tumor cells.

\section{Expression vector construction}

The sequences of the miR-497 precursor (MIR497) and the miR-34a precursor (MIR34A) were amplified with oligonucleotide primers synthesized by Invitrogen (Figure S4). MIR497 and MIR34A were then inserted individually into the pcDNA $^{\mathrm{TM}} 6.2-\mathrm{GW} / \mathrm{EmGFPmiR}$ vector (Invitrogen) using the BLOCK-iT ${ }^{\mathrm{TM}}$ Pol II miR RNAi Expression Vector Kit (Invitrogen), to generate the expression constructs Hi-miR497 and Hi-miR34a, respectively. These were verified by DNA sequencing with the primer 5'-CTCTAGATCAACCACTTTGT-3' in an ABI Prism 373 Genetic Analyzer (Applied Biosystems). The empty pcDNA ${ }^{\mathrm{TM}} 6.2-\mathrm{GW} / \mathrm{EmGFPmiR}$ vector was used as the negative control (mock). To investigate the cooperative activities of miR-497 and miR-34a, we used the isocaudomers BamHI (NEB, Beverly, MA) and BglII (NEB) to ligate both MIR497 and MIR34A into the vector to generate the expression construct Hi-miR497/34a, which was confirmed by DNA sequencing.

A clone of the green fluorescent protein (GFP)tagged cDNA [including complete 3'-UTR encoding human CCNE1 (NM_001238.2)], was bought from Origene (Rockville, MD) as transfection-ready plasmid DNA. The neomycin-resistance gene is expressed downstream from the SV40 promoter in the same vector, which permits the positive selection of transfected cells. To construct cells stably expressing CCNE1, A549 cells were transfected with the plasmid DNA and selected with neomycin $(0.5 \mathrm{mg} / \mathrm{mL})$.

\section{Statistical analysis}

All assays were performed in triplicate in three independent experiments, and all data are expressed as the mean \pm SD. Statistical differences between two groups were evaluated with the two-tailed Student's $t$ test and analysis of variance (ANOVA) was used for multiple comparisons. In all cases, $P<0.05$ was considered significant. All statistical tests were performed with the statistical analysis software IBM SPSS Statistics 20 for Mac (International Business Machines Corporation, New York, NY).

\section{ACKNOWLEDGMENTS}

We thank Chengjie Liang from the Experimental Animal Center of Guangzhou Medical University for raising the nude mice used as the animal model in this study.

\section{FUNDING}

This work was supported by the National Natural Science Foundation of China (81172633, 30972443, 30771780 to J.Y.; 81202235 to H.Z.), Research Fund for Doctoral Program of Higher Education of China (20114423110002 to J.Y.), University Talent Program of Guangdong (2013-164 to J.Y.), Bureau of Science and Information Technology of Guangzhou Municipality (2013J4100034 to H.Z.) and Innovation Team Grant of Guangzhou Municipal Education Department (13C06 to Z.Y.).

\section{CONFLICT OF INTEREST}

The authors declare that they have no conflicts of interest. 


\section{Abbreviations}

miRNA, microRNA; 3'-UTR, 3'-untranslated region; FBS, fetal bovine serum; siRNA, small interfering RNA; CCK-8, cell counting kit-8; NC inhibitor, miRNA inhibitor negative control; NC mimic, miRNA mimic negative control; qRT-PCR, quantitative real-time polymerase chain reaction; RT, reverse transcription; $\mathrm{SD}$, standard deviation.

\section{REFERENCES}

1. Filipowicz W, Bhattacharyya SN, Sonenberg N. Mechanisms of post-transcriptional regulation by microRNAs: are the answers in sight? Nat Rev Genet. 2008; 9: 102-114.

2. Lee Y, Ahn C, Han JJ, Choi H, Kim J, Yim J, Lee J, Provost P, Radmark O, Kim S, Kim VN. The nuclear RNase III Drosha initiates microRNA processing. Nature. 2003; 425: 415-419.

3. Lewis BP, Burge CB, Bartel DP. Conserved seed pairing, often flanked by adenosines, indicates that thousands of human genes are microRNA targets. Cell. 2005; 120: 15-20.

4. Brennecke J, Hipfner DR, Stark A, Russell RB, Cohen SM. bantam encodes a developmentally regulated microRNA that controls cell proliferation and regulates the proapoptotic gene hid in Drosophila. Cell. 2003; 113: 25-36.

5. Cimmino A, Calin GA, Fabbri M, Iorio MV, Ferracin M, Shimizu M, Wojcik SE, Aqeilan RI, Zupo S, Dono M, Rassenti L, Alder H, Volinia S, et al. miR-15 and miR-16 induce apoptosis by targeting BCL2. Proc Natl Acad Sci U S A. 2005; 102: 13944-13949.

6. He L, He X, Lim LP, De Stanchina E, Xuan Z, Liang Y, Xue W, Zender L, Magnus J, Ridzon D, Jackson AL, Linsley PS, Chen C, et al. A microRNA component of the p53 tumour suppressor network. Nature. 2007; 447: 11301134.

7. Hermeking H. The miR-34 family in cancer and apoptosis. Cell Death Differ. 2010; 17: 193-199.

8. Kim YK, Yu J, Han TS, Park SY, Namkoong B, Kim DH, Hur K, Yoo MW, Lee HJ, Yang HK, Kim VN. Functional links between clustered microRNAs: suppression of cellcycle inhibitors by microRNA clusters in gastric cancer. Nucleic Acids Res. 2009; 37: 1672-1681.

9. Melton C, Judson RL, Blelloch R. Opposing microRNA families regulate self-renewal in mouse embryonic stem cells. Nature. 2010; 463: 621-626.

10. Yoo AS, Staahl BT, Chen L, Crabtree GR. MicroRNAmediated switching of chromatin-remodelling complexes in neural development. Nature. 2009; 460: 642-646.

11. Oeztuerk-Winder F, Guinot A, Ochalek A, Ventura JJ. Regulation of human lung alveolar multipotent cells by a novel p38alpha MAPK/miR-17-92 axis. EMBO J. 2012; 31: 3431-3441.
12. Kim K, Chadalapaka G, Lee SO, Yamada D, Sastre-Garau X, Defossez PA, Park YY, Lee JS, Safe S. Identification of oncogenic microRNA-17-92/ZBTB4/specificity protein axis in breast cancer. Oncogene. 2012; 31: 1034-1044.

13. Jevnaker AM, Khuu C, Kjole E, Bryne M, Osmundsen H. Expression of members of the miRNA17-92 cluster during development and in carcinogenesis. J Cell Physiol. 2011; 226: 2257-2266.

14. Aqeilan RI, Calin GA, Croce CM. miR-15a and miR-16-1 in cancer: discovery, function and future perspectives. Cell Death Differ. 2010; 17: 215-220.

15. Bonci D, Coppola V, Musumeci M, Addario A, Giuffrida R, Memeo L, D’Urso L, Pagliuca A, Biffoni M, Labbaye C, Bartucci M, Muto G, Peschle C, et al. The miR-15amiR-16-1 cluster controls prostate cancer by targeting multiple oncogenic activities. Nat Med. 2008; 14: 12711277.

16. Ventura A, Young AG, Winslow MM, Lintault L, Meissner A, Erkeland SJ, Newman J, Bronson RT, Crowley D, Stone JR, Jaenisch R, Sharp PA, Jacks T. Targeted deletion reveals essential and overlapping functions of the miR-17 through 92 family of miRNA clusters. Cell. 2008; 132: 875886.

17. Han Z, Yang Q, Liu B, Wu J, Li Y, Yang C, Jiang Y. MicroRNA-622 functions as a tumor suppressor by targeting K-Ras and enhancing the anticarcinogenic effect of resveratrol. Carcinogenesis. 2012; 33: 131-139.

18. Taylor-Harding B, Aspuria PJ, Agadjanian H, Cheon DJ, Mizuno T, Greenberg D, Allen JR, Spurka L, Funari V, Spiteri E, Wang Q, Orsulic S, Walsh C, et al. Cyclin E1 and RTK/RAS signaling drive CDK inhibitor resistance via activation of E2F and ETS. Oncotarget. 2014; Dec 22. Epub ahead of print.

19. Freemantle SJ, Dmitrovsky E. Cyclin E transgenic mice: discovery tools for lung cancer biology, therapy, and prevention. Cancer Prev Res. 2010; 3: 1513-1518.

20. Ma Y, Fiering S, Black C, Liu X, Yuan Z, Memoli VA, Robbins DJ, Bentley HA, Tsongalis GJ, Demidenko E, Freemantle SJ, Dmitrovsky E. Transgenic cyclin E triggers dysplasia and multiple pulmonary adenocarcinomas. Proc Natl Acad Sci U S A. 2007; 104: 4089-4094.

21. Donnellan R, Chetty R. Cyclin E in human cancers. FASEB J. 1999; 13: 773-780.

22. Huang LN, Wang DS, Chen YQ, Li W, Hu FD, Gong BL, Zhao CL, Jia W. Meta-analysis for cyclin E in lung cancer survival. Clin Chim Acta. 2012; 413: 663-668.

23. Ma ZL, Hou PP, Li YL, Wang DT, Yuan TW, Wei JL, Zhao BT, Lou JT, Zhao XT, Jin Y, Jin YX. MicroRNA$34 \mathrm{a}$ inhibits the proliferation and promotes the apoptosis of non-small cell lung cancer H1299 cell line by targeting TGFbetaR2. Tumour Biol. 2014; Dec 13. Epub ahead of print.

24. Tafsiri E, Darbouy M, Shadmehr MB, Zagryazhskaya A, Alizadeh J, Karimipoor M. Expression of miRNAs in 
non-small-cell lung carcinomas and their association with clinicopathological features. Tumour Biol. 2014; Nov 11. Epub ahead of print.

25. Son JW, Kim YJ, Cho HM, Lee SY, Jang JS, Choi JE, Lee JU, Kang MG, Lee YM, Kwon SJ, Choi E, Na MJ, Park JY. MicroRNA Expression Profiles in Korean Non-Small Cell Lung Cancer. Tuberc Respir Dis. 2009; 67: 413-421.

26. Zhao WY, Wang Y, An ZJ, Shi CG, Zhu GA, Wang B, Lu MY, Pan CK, Chen P. Downregulation of miR-497 promotes tumor growth and angiogenesis by targeting HDGF in non-small cell lung cancer. Biochem Biophys Res Commun. 2013; 435: 466-471.

27. Mudduluru G, Ceppi P, Kumarswamy R, Scagliotti GV, Papotti M, Allgayer H. Regulation of Axl receptor tyrosine kinase expression by miR-34a and miR-199a/b in solid cancer. Oncogene. 2011; 30: 2888-2899.

28. Ji X, Wang Z, Geamanu A, Goja A, Sarkar FH, Gupta SV. Delta-tocotrienol suppresses Notch-1 pathway by upregulating miR-34a in nonsmall cell lung cancer cells. Int J Cancer. 2012; 131: 2668-2677.

29. Okada N, Lin CP, Ribeiro MC, Biton A, Lai G, He X, Bu P, Vogel H, Jablons DM, Keller AC, Wilkinson JE, He B, Speed TP, et al. A positive feedback between p53 and miR34 miRNAs mediates tumor suppression. Genes Dev. 2014; 28: 438-450.

30. Calin GA, Sevignani C, Dan Dumitru C, Hyslop T, Noch E, Yendamuri S, Shimizu M, Rattan S, Bullrich F, Negrini M, Croce CM. Human microRNA genes are frequently located at fragile sites and genomic regions involved in cancers. Proc Natl Acad Sci U S A. 2004; 101: 2999-3004.

31. Bailey-Wilson JE, Amos CI, Pinney SM, Petersen GM, de Andrade M, Wiest JS, Fain P, Schwartz AG, You M, Franklin W, Klein C, Gazdar A, Rothschild H, et al. A major lung cancer susceptibility locus maps to chromosome 6q23-25. Am J Hum Genet. 2004; 75: 460-474.

32. Tseng RC, Chang JW, Hsien FJ, Chang YH, Hsiao CF, Chen JT, Chen CY, Jou YS, Wang YC. Genomewide loss of heterozygosity and its clinical associations in non small cell lung cancer. Int J Cancer. 2005; 117: 241-247.

33. Agostini M, Knight RA. miR-34: from bench to bedside. Oncotarget. 2014; 5: 872-881.

34. Siemens H, Jackstadt R, Kaller M, Hermeking $H$. Repression of c-Kit by p53 is mediated by miR-34 and is associated with reduced chemoresistance, migration and stemness. Oncotarget. 2013; 4: 1399-1415.

35. Girard L, Zochbauer-Muller S, Virmani AK, Gazdar AF, Minna JD. Genome-wide allelotyping of lung cancer identifies new regions of allelic loss, differences between small cell lung cancer and non-small cell lung cancer, and loci clustering. Cancer Res. 2000; 60: 4894-4906.

36. Sun F, Fu H, Liu Q, Tie Y, Zhu J, Xing R, Sun Z, Zheng X. Downregulation of CCND1 and CDK6 by miR-34a induces cell cycle arrest. FEBS Lett. 2008; 582: 1564-1568.

37. Zhu W, Zhu D, Lu S, Wang T, Wang J, Jiang B, Shu Y,
Liu P. miR-497 modulates multidrug resistance of human cancer cell lines by targeting BCL2. Med Oncol. 2012; 29: 384-391.

38. Fukuse T, Hirata T, Naiki H, Hitomi S, Wada H. Prognostic significance of cyclin $\mathrm{E}$ overexpression in resected nonsmall cell lung cancer. Cancer Res. 2000; 60: 242-244.

39. Schraml P, Bucher C, Bissig H, Nocito A, Haas P, Wilber K, Seelig S, Kononen J, Mihatsch MJ, Dirnhofer S, Sauter G. Cyclin E overexpression and amplification in human tumours. J Pathol. 2003; 200: 375-382.

40. Muller-Tidow C, Metzger R, Kugler K, Diederichs S, Idos G, Thomas M, Dockhorn-Dworniczak B, Schneider PM, Koeffler HP, Berdel WE, Serve H. Cyclin E is the only cyclin-dependent kinase 2-associated cyclin that predicts metastasis and survival in early stage non-small cell lung cancer. Cancer Res. 2001; 61: 647-653.

41. Liu Q, Fu H, Sun F, Zhang H, Tie Y, Zhu J, Xing R, Sun Z, Zheng X. miR-16 family induces cell cycle arrest by regulating multiple cell cycle genes. Nucleic Acids Res. 2008; 36: 5391-5404.

42. Liu X, Sempere LF, Galimberti F, Freemantle SJ, Black C, Dragnev KH, Ma Y, Fiering S, Memoli V, Li H, DiRenzo $\mathrm{J}$, Korc M, Cole CN, et al. Uncovering growth-suppressive MicroRNAs in lung cancer. Clin Cancer Res. 2009; 15: 1177-1183.

43. Bommer GT, Gerin I, Feng Y, Kaczorowski AJ, Kuick R, Love RE, Zhai Y, Giordano TJ, Qin ZS, Moore BB, MacDougald OA, Cho KR, Fearon ER. p53-mediated activation of miRNA34 candidate tumor-suppressor genes. Curr Biol. 2007; 17: 1298-1307.

44. Liu C, Kelnar K, Liu B, Chen X, Calhoun-Davis T, Li H, Patrawala L, Yan H, Jeter C, Honorio S, Wiggins JF, Bader AG, Fagin R, et al. The microRNA miR-34a inhibits prostate cancer stem cells and metastasis by directly repressing CD44. Nat Med. 2011; 17: 211-215.

45. Yadav S, Pandey A, Shukla A, Talwelkar SS, Kumar A, Pant AB, Parmar D. miR-497 and miR-302b regulate ethanol-induced neuronal cell death through BCL2 protein and cyclin D2. J Biol Chem. 2011; 286: 37347-37357.

46. Alvarez-Saavedra E, Horvitz HR. Many families of C. elegans microRNAs are not essential for development or viability. Curr Biol. 2010; 20: 367-373.

47. Miska EA, Alvarez-Saavedra E, Abbott AL, Lau NC, Hellman AB, McGonagle SM, Bartel DP, Ambros VR, Horvitz HR. Most Caenorhabditis elegans microRNAs are individually not essential for development or viability. PLoS Genet. 2007; 3: e215.

48. Bartel DP. MicroRNAs: Target Recognition and Regulatory Functions. Cell. 2009; 136: 215-233.

49. Krek A, Grun D, Poy MN, Wolf R, Rosenberg L, Epstein EJ, MacMenamin P, da Piedade I, Gunsalus KC, Stoffel M, Rajewsky N. Combinatorial microRNA target predictions. Nat Genet. 2005; 37: 495-500.

50. Kertesz M, Iovino N, Unnerstall U, Gaul U, Segal E. The 
role of site accessibility in microRNA target recognition. Nat Genet. 2007; 39: 1278-1284.

51. Freemantle SJ, Dmitrovsky E. Cyclin E transgenic mice: discovery tools for lung cancer biology, therapy, and prevention. Cancer Prev Res (Phila). 2010; 3: 1513-1518.

52. Nakayama N, Nakayama K, Shamima Y, Ishikawa M, Katagiri A, Iida K, Miyazaki K. Gene amplification CCNE1 is related to poor survival and potential therapeutic target in ovarian cancer. Cancer. 2010; 116: 2621-2634.

53. Liang Y, Gao H, Lin SY, Goss JA, Brunicardi FC, Li $\mathrm{K}$. siRNA-based targeting of cyclin $\mathrm{E}$ overexpression inhibits breast cancer cell growth and suppresses tumor development in breast cancer mouse model. PloS one. 2010; 5: e12860.

54. Shaye A, Sahin A, Hao Q, Hunt K, Keyomarsi K, Bedrosian I. Cyclin E deregulation is an early event in the development of breast cancer. Breast Cancer Res Treat. 2009; 115: 651659.

55. Furuta M, Kozaki K, Tanimoto K, Tanaka S, Arii S, Shimamura T, Niida A, Miyano S, Inazawa J. The tumorsuppressive miR-497-195 cluster targets multiple cell-cycle regulators in hepatocellular carcinoma. PloS one. 2013; 8: e60155.

56. Di Martino MT, Leone E, Amodio N, Foresta U, Lionetti M, Pitari MR, Cantafio ME, Gulla A, Conforti F, Morelli E, Tomaino V, Rossi M, Negrini M, et al. Synthetic miR-34a mimics as a novel therapeutic agent for multiple myeloma: in vitro and in vivo evidence. Clin Cancer Res. 2012; 18: 6260-6270.

57. Welch C, Chen Y, Stallings RL. MicroRNA-34a functions as a potential tumor suppressor by inducing apoptosis in neuroblastoma cells. Oncogene. 2007; 26: 5017-5022. 